\title{
МИСТЕЦТВОЗНАВСТВО
}

\author{
DOI: https://doi.org/10.32839/2304-5809/2021-3-91-30 \\ УДК $130.2 ; 7.01 ; 7.03 ; 7.04$
}

Дротенко B.I.

Дрогобицький державний педагогічний університет імені Івана Франка

\section{СЕМІОТИКА ІКОНОПИСУ ТА СТИЛІСТИКА ІКОНИ В КОНТЕКСТІ КУЛЬТУРНО-МИСТЕЦЬКОЇ ТРАДИЦІЇ}

\begin{abstract}
Анотація. Стаття присвячена проблемам семіотики іконопису та іконології як методу інтерпретації семантики ікони, іï опосередкування соціокультурним контекстом. Особливістю українського іконопису $е$ поєднання візантійського стилю зі стилями західноєвропейського мистецтва і розробка власної версії цих стилів. Концепт ікони визначає ії як культурний артефакт і розкриває взаємовпливи українського живопису та іконопису. Художній контекст семантики ікони пов'язаний 3 пошуками поєднання національної традиції та авангардного мислення в образотворчому мистецтві. Йдеться про взаємозв'язок художніх засобів виразності світських жанрів та композиційно-колористичних канонів сакрального мистецтва. Символіка світла, кольору, простору і принцип розташування об'ектів зображення відповідають канонам сакрального. Сюжетність, ефект особистості, виразність та мальовничість форми свідчать про світський контекст. Компактність сюжету, не зважаючи на персоніфікацію та індивідуалізоване тлумачення, викликає цілісне сприйняття Божественної присутності. Трансцендентальний вимір ікони визначається антиноміею невидимого у видимому, незображеного у зображеному; художній вимір ікони виявляе співвіднесення іконографрічного канону з каноном фольклорних традицій. Перспективи досліджень іконопису пов’язані з методом інтерпретації його об’єктів. Метод іконології виявляє за змістом, стилем зображення та технікою виконання семантичне значення і визначає тенденцію розвитку сакрального мистецтва.
\end{abstract}

Ключові слова: семіотика іконопису, семантика ікони, стилі іконотворчості, символічність сакрального простору, іконологія.

Drotenko Valentyna Drohobych Ivan Franko State Pedagogical University

\section{SEMIOTICS OF ICON PAINTING AND STYLISTICS OF THE ICON IN THE CONTEXT OF CULTURAL AND ARTISTIC TRADITION}

Summary. The article is devoted to the problems of semiotics of icon painting and iconology as a method of interpretation of icon semantics, its mediation by the socio-cultural context. The peculiarity of Ukrainian icon painting is the combination of the Byzantine style with the styles of Western European art and the development of its own version of these styles. The concept of the icon defines it as a cultural artifact and reveals the mutual influences of Ukrainian painting and iconography. The artistic context of the semantics of the icon is connected with the search for a combination of national tradition and avant-garde thinking in the fine arts. It is a question of interrelation of artistic means of expression of secular genres and compositional-coloristic canons of sacred art. The symbolism of light, color, space and the principle of arrangement of the objects of the image correspond to the canons of the sacred. The plot, the effect of personality, expressiveness and picturesqueness of the form testify to the secular context. The compactness of the plot, despite the personification and individualized interpretation, evokes a holistic perception of the Divine presence. The transcendental dimension of the icon is determined by the antinomy of the invisible in the visible, the unimaged in the depicted; the artistic dimension of the icon reveals the correlation of the iconographic canon with the canon of folk traditions. The theoretical basis of modern research of icon painting is the identification of its transformations under certain socio-cultural conditions and in the system of sacred art; analysis of observance or violation of iconographic canons in accordance with the traditions of exegesis; identification of ethnic, stylistic, typological features of the Ukrainian icon. Prospects for the study of icon painting are related to the method of interpretation of its objects. The method of iconology reveals the semantic meaning of the content, style of image and technique of execution and determines the trend of development of sacred art.

Keywords: semiotics of icon painting, semantics of icons, styles of icon making, symbolism of sacred space, iconology.

Постановка проблеми: визначення способу усвідомлення селіотики іконопису та методу інтерпретащії селантики ікони з метою вияву опосередкованості її знаково-символічного змісту й стилістично-художньої фрорми соціокультурним контекстом.

Аналіз останніх досліджень і публікацій. Джерельною базою теорії та історії іконопису $е$, насамперед, ббілособбські та теологічні праці С. С. Аверінцева, В. В. Бичкова, Я. Креховецько- го, Б. А. Успенського, П. Флоренського. Культурологічний та мистеитвознавчий аналіз із застосуванням іконографічного методу дослідження здійснено у працях сучасних науковців Д. Крвавича, В. Лепахіна, В. Овсійчука, О. Осадчої, О. Пономаревської, Ю. Попенюк, Н. Руско, В. Свєнціцької, П. Скопа, Д. Степовика, О. Тріски, І. Федя.

П. Скоп $[9 ; 10]$ визначив проблематику стильових трансформащій у сакральному малярстві Галичини початку XVII ст. - часу, що передував 
культурі бароко. На підставі наукових спостережень над групою пам'яток іконопису автором здійснено узагальнення щодо характерних тенденщій у зміні стильової парадигми малярського письма.

О. Тріска [12] дослідила народну ікону на склі як вид народної декоративної творчості, мистецький френомен, цілісне художне явище другої половини XVIII-XIX століть з погляду зіставлення української ікони в загальноєвропейському контексті. Авторка зауважила, що незвична техніка виконання, застосована народними майстрами для створення ікон, не лише спричинила появу нового виду творчості, але стала визначальною в розвитку іконопису на склі.

Н. Руско [8] сформулювала особливості галицького іконопису кінця XIX - початку XX століть й актуалізувала в науковому дискурсі проблематику галицького сакрального мистецтва в контексті української духовної культури. В умовах євроінтеграції та секуляризації окреслила необхідність осмислення втраченої сакральної спадщини, а також регенерації українського іконопису як цілісного мистецького явища.

I. Федь [13; 14] увиразнив вагомість сакрального мистецтва як стабілізуючого фрактора, а ікону як його узагальнення, оскільки в ній закладено гармонізацію суспільних процесів, культуризацію особистості, пошук досконалих фрорм буденного. Автор дослідив не лише релігійно-художній зміст концепту ікони, але як вічну категорію культури: ікона та іконічне - категорії, що розкривають глибинні основи людської духовності.

Слід зауважити також праці В. Лепахіна [2] про іконічне як парадигмальне узагальнення характерних рис сакральної культури; дослідження Д. Степовика [11] про рефрлексивні фрункції ікони щодо формування нащіональної свідомості.

О. Осадча [4; 5] окреслила проблематику методологічних засад іконології, пов'язаних зі створенням іконографічного образу: відображення принципів іконічності в іконографічному образі; поєднання іконографічної традиції та новаторства в українському іконописі.

Виділення невирішених раніше частин загальної проблеми. У статті розглянуто з позицій семіотики культури і мистецтва знаковосимволічний зміст і стилістично-художні форми іконотворчості із застосуванням іконології як методу символічної інтерпретації об'єктів сакрального мистецтва.

Мета статті. Розглянути український іконопис 3 погляду концепту ікони як культурного артефракту, що синтезуе художній контекст національної традищї̈, здобутки українського живопису, та символізм авангардного мислення в образотворчому мистецтві.

Поняття вишуканості неодмінно пов'язане з поняттям стилю, а мистецтво - 3 поняттям пре красного. У процесі утворення стилю в мистецтві спостерігаються періоди, коли прекрасному протиставляється низьке й потворне. Проте це не суперечить фундаментальній тезі, що підставою кожного стилю $є$ розуміння прекрасного - iдеал краси. У сакральному мистецтві, яке надихає людину на подолання страху смерті й усвідомлення вічного життя, ідеал прекрасного, виражений через мистецький стиль, приймає довершених форм. Українське сакральне мистецтво в частині іконотворчості виробило свій власний стиль, відмінний від автохтонного візантійського. Українська ікона вже 3 початків свого виникнення $\epsilon$ унікальним явищем. Поєднання візантизму 3 мистецькими стилями західноєвропейського мистецтва (романським, готичним, ренесансним, бароко, романтизмом і класицизмом) свідчить не тільки про стильову адаптацію, але про синкретизл, вироблення власних варіантів цих стилів, піднесення яких припадає на період XV-XIX століття. Іконопис упродовж століть обумовлював розвиток українського живопису. Стильова еволюція іконопису проявляе особливості естетики та силволізму ікони і, водночас, концептуалізуе ікону як культурний артеббакт.

Виклад основного матеріалу. Зазначимо, що дослідження естетичної цінності східнохристиянського іконопису розпочалося мистецтвознавцями лише на початку XX століття. За версією фахівця 3 релігійної естетики Віктора Бичкова, розвідки естетичної цінності iконописної традицї̈, дослідження мистецького жанpy іконопису пов'язані 3 художньо-естетичними пошукали модернізлу кінця XIX - початку ХХ століть. Втім, на думку О. Пресіч [7], пояснення В. Бичкова недостатньо враховуе художній контекст поняття "символізм» кінця XIX - початку XX ст., зокрема, у сенсі літературно-фрілософрської течії, що пов'язана 3 пошуками поєднання епістелологї, етики та естетики. По-друге, на засадах принципу історизму у цей період сdрормувалося ставлення до іконопису не тільки як до мистецтва сакрального, але, насамперед, як до історичної пам'ятки національної культури, що обумовлене націєтворчими процесами, котрі потребували дослідження, реставрації та започаткування музейних колекцій. Як підкреслює О. Пресіч, «Естетика східнослов'янської ікони, заснованої на неоплатонічних ідеях візантійського богослов'я, з часом увібрала в себе місцевий колорит і західні впливи - аж до того часу, коли в період націєтворення й авангардного мистецтва було заново «відкрито» колористичну i двовимірну художню мову давньоруського іконопису. Це дало поштовх до розвитку семіотичних досліджень про символізм ікон. Що ж до стилістичної еволюції іконопису після середини XIII ст., то «відкрите», «інклюзивне» розуміння національної традиції (при усвідомленні їі конструйованого характеру) здається нам продуктивнішим, ніж закам'яніле визнання як «національної» естетики лише канонічного іконопису» [7].

Дослідники естетики іконопису - Павло Муратов, Борис Успенський, Павло Флоренський, Сергій Булгаков, Володимир Лоський - сфрормулювали типові стилістичні ознаки, силволічний зміст, принципи організації простору в іконі, окреслили спеціальні (умовно-абстрактні) $x у д о ж-$ ньо-зображальні засоби, що відокремлюють простір глядача від простору ікони як простору сакрального, який має безконечну тривалість і $€$ «зовнішнім вираженням преображення людини». На думку В. Бичкова, сакральне мистецтво зорієнтоване на створення особливого духовного середовища, в якому здійснюеться «візуально-споглядальне спілкування віруючого з Богом» [1, с. 467]. 3 погляду В. Овсійчука, це середовище - місце взаємного переходу світів - видимого й невиди- 
мого, своєрідне «вікно», що відчиняється лише під час богослужіння. Саме тоді ікони стають «реальними символами», через які люди відчувають себе причетними до світу небесного [3, с. 305].

Символ у мистецтві - це водночас і образ, i знак. Структура символу відтворюе через осібне явище цільний образ світу. На переконання Павла Флоренського, дійсне мистецтво виникає при сходженні душі з "горнього світу», коли вона здатна відображати сприйняті там ідеї у символічних образах. Мистецтво орієнтоване на виявлення нової, ще невідомої нам реальності. Як зазначає Д. Крвавич, символічний образ у мистецтві - це сама реальність, але вищого рівня, ніж реальність видимого світу; найповніше така реальність властива іконі.

Осмислення сутності людини у модусах сакрального мистецтва відбувається на підставі усвідомлення історичної едності християнської символіки з ученням Ареопагіта та фрілософрією неоплатонізму. Ареопагіт розробив систему естетичного сприймання всесвіту як ієрархії осяйного світла; церква - ідеальна людська спільнота, що безпосередньо продовжує ієрархію ангелів, специфічне віддзеркалення позаземного святого світла у чистих дзеркалах, що передають промінь одне одному. Символ світлоносної речовини усіляко матеріалізуеться у сакральному мистецтві. Божественне світло - це рівночасно сяючий німб навколо голови Бога-Отця, Христа, Богородиці, святих. Золоте тло - ідеальний символ нескінченної світлової енергії, безмежності, істини, надчуттевості. Світлоносні барви є виявом духовності, де кожна символізуе космічні субстанції стихії та людські моральні якості. Золото і скло матеріальні виразники світла, божественної осяйності. Краса-світло трансформуеться у мозаїках, вітражах, окладах ікон.

Отже, символіка світла має специфічне естетичне значення - краса як світло. Світлоносність краси, спорідненість світла з душею - це ключові атрибути християнського віровчення. У композищійній системі ікони співвідносяться реальний, потойбічний та містичний світи. Стрижневим змістом композиції ікони $є$ протиставлення краси плоті і краси Духу. Це досягається засобом колірних співвідношень, композиційних вузлів, чіткої спрямованості магістральних ліній в іконі та інших засобів художньої виразності.

Ікона існує в контексті архітектурної композиції храму, підгрунттям якої є чотирикутник і напівсорера (баня). Поєднуючись у різних комбінаціях, ці форми утворюють довершений художній ансамбль. Вони є структурними елементами не тільки у побудові сакрального простору храму, але й в іконографічній композищіі. Чотирикутник символізуе тварний світ, а напівсфера - світ Божественний. Поєднуючись, вони персоніфрікують Христа, символізуючи едність природи божественної і людської. Внутрішня геометрія ікони грунтуеться на формі кола - овал, еліпс, спіраль, парабола. Такий принцип побудови композиції дозволяе сконцентрувати всі елементи зображення у цілісну структуру.

Важливу роль у сприйнятті ікони відіграє перспектива - особлива система передачі просторових характеристик на двомірну площину зображення. Йдеться про лінійну прялу, зворот- ну та сфберичну перспективу. В системі прямої перспективи суттевим $є$ едрект, який отримує глядач в заданий момент із заданої точки. Пряма перспектива - основний прийом конструювання художнього простору, не залежний від загального контексту культури і зберігає своє значення в образотворчих мистецтвах будь-яких епох. Вона розрахована на нерухому точку споглядання i передбачає єдину точку сходження на лінії горизонту (предмети пропорційно зменшуються, віддаляючись від переднього плану).

В системі зворотної перспективи несуттеві різноманітні розломи фором, їх спотворення, у порівнянні 3 тим, що можна бачити 3 одніеї точки; проте особливо важливо передати враження від предмета, яке ми реально отримуємо, сприймаючи предмет з різних боків. Це прийом, коли предмети збільшуються разом 3 віддаленням від глядача. Зворотна перспектива створюється лініями, які розходяться вдалечінь, спорудами, предметами, кольором. Швидше сприймаються яскраві кольори, i, навпаки, менш активно - темні. Різниця в повноті сприйняття породжує едект того, що яскраві тони розташовані ніби ближче, а приглушені здаються віддаленими. Створене зображення при цьому має кілька горизонтів, точок зору. Центр сходження ліній знаходиться не на горизонті, а всередині самого спостерігача. Єдиний символічний простір, зорієнтований на глядача, окреслюе його духовний зв'язок із світом символічних образів. Зворотна перспектива виконуе завдання втілення надчуттевого сакрального змісту в зриму, але позбавлену матеріальності, конкретну форму. Вона простежуеться в мистецтві XI-XII ст., і концептуально зумовлена світоглядними мотивами.

Сдерична перспектива - особливий спосіб організації живописного простору на площині ікони або розпису стіни, склепіння, купола, який полягає в ілюзорному поглибленні зорового центру, що збігаеться з геометричним центром композиції, і розташуванні інших елементів в уявному сферичному просторі. У сореричній перспективі всі лінії глибини матимуть точку сходження в головній точці і залишатимуться чітко прямими. Строго прямими будуть головна вертикаль і лінія горизонту. Всі інші лінії з віддаленням від головної точки все більше згинатимуться, трансформуючись у коло. Лінії, що не проходять крізь центр, продовжуючись, утворюють напівеліпс.

Ікона являе світ абсолютного буття назустріч глядачеві. Принцип діагонального розташування ббігур на площині (асиметрія зображення святого щодо центральної вертикальної осі) створюе відчуття «виходу» фрігури з живописної площини назовні. У побудові об'єктів зображення й у загальній ритмічній будові простору ікони застосовується прийом контрапункту - зіткнення різноспрямованих сил руху. Архітектоніка ікони утворена S-подібними лініями, що утверджують синергетичні зв'язки між усіма об'єктами в композиції ікони та 3 глядачем. При зовнішній статиці зображення цей прийом створюе ілюзію внутрішньої динаміки. Ефект «виходу» образу 3 площини ікони у простір глядача створюеться поєднанням колірних співвідношень за принципом оптичного змішування фрарб, переходу кольорів від темного теплого санкірного тону до світлого 
холодного. Отже, завдяки художнім прийомам сореричної перспективи формуеться тривилірність простору ікони.

Основна тенденщія української іконографрї це прагнення до виразності деталей, аксесуарів та побутових предметів у зображенні лику святих i апостолів, бажання реально відобразити драматичний зміст ситуації, стремління до синтезу природи й історії, живопису й архітектури у зображенні панорами міст та окремих споруд, масштабно співвідносних людині. Зображення святих і апостолів свідчать про спроби митців до пізнання людського характеру, що стало головною ознакою ренесансного портрету в европейській культурі. В українському живопису ренесансний іконопис вплинув на формування портретного та історичного жанрів. I навпаки, запозичив у світських жанрів - портрету, пейзажу, побутової картини - їхні мистецькі засоби. Ренесансні ікони позбулись аскетичності, непорушності образів, натомість звернулися до пропорційності людської фрігури, зменшилась монументальність, збільшився декор. Митці почали надавати обличчям святих слов'янських рис. Такі лики стали сприйматися як норма. Особливістю українських ренесансних ікон $є$ яскраво виражена сюжетність, багатоперсонажність. Проте композиційні канони і символіка кольорів залишились сталими.

Бароковий іконопис в українському сакральному живопису другої половини XVII-XVIII століть означений традиційною тематикою та іконографією. Втім спостерігається трансформації у стилістиці відображення та часткове урізноманітнення сюжетів, зміни у взаємозалежності між фрормою зображення та його сенсом, відображенням i реальністю, твором і глядачем. Ікона стає предметом естетичного сприймання. 3'являються ефбект особистості в іконічному зображенні (ікона ніби звертається до глядача), а також - живописність як виразність форми, яка поза релігійним смислом впливає на почуття. Композиція ікон асиметрична, утім урівноважена за масами і стримана тонально. Майже в усіх іконах ликам святих властивий проникливий nсихологізл. Водночас у іконах помітні авторитети середньовічного іконопису, середньовічної символіки кольорів. Зокрема, цілісність і компактність груп персонажів сюжету попри персоніфрікацію та індивідуалізоване тлумачення міміки, жестів, одягу налаштовують на цілісне сприймання Божественної присутності.

Бароковому іконопису властива повітряна перспектива як спосіб створення ілюзї глибини простору за допомогою тональної зміни зображення предметів. Передні об'єкти і предмети художник малює чітко, детально, контрастно, а силуети об'єктів далекого плану зображуються ніби розмитими, менш чіткими, менш деталізованими, разом з віддалення втрачається їх об'ем i форома. Вважають, що повітряна перспектива це синтез тональної та колірної перспектив. Однак відчування простору не позбавлене принципу ієрархічних зв'язків, системи композиційних і масштабних співвідношень відповідно до семантики та символічності об'єктів умовного простору. Попри характерну для бароко повітряну перспективу використовується й зворотна перспектива.
Вплив романтизму на іконопис спостерігається у перенесені декоративних акцентів із зовнішніх фрорм (обрамлення, тло, одяг святих) у внутрішню структуру образу (поєднання яскравих тонів і відтінків) у витонченість малярства (сорумато, лесування - прийоми повітряної перспективи). Замість драматизму й падосності підкреслюються ліричні почуття, лагідність, мрійливість. Натомість класицизм викликав уніфрікацію у сакральному мистецтві. Проте водночас цей стиль приніс і позитивні риси, започатковані ще у добу ренесансу: чіткість композиції, довершеність форми, майстерність рисунка, науковий підхід до побудови простору, перспективи, масштабу, гармонійність і симетрію.

Неповторні особливості української ікони беруть початок від народного розуління прекрасного. Це - витончений, добірний, орнаментальний стиль української народної творчості, народного образотворчого та декоративного мистецтва. Починаючи 3 XV ст., народна декоративна традиція стала істотною у формуванні національного стилю. 3 кінця XVIII й упродовж XIX століть виразником національних художніх традицій стала народна ікона. Мистецтво селянського примітиву протиставило світському академічному спрямуванню профресійного іконопису життєдайнiсть $i$ uілісність художнього впливу. Народний іконопис відмовляеться від загальноприйнятих стереотипів і канонів. Йому притаманні витончене відчуття стилю, оригінальна франтазія, проникливе бачення. Опираючись на поетичну образність народного уявлення, народні іконописці створили образи, котрі приваблюють своєю невимушеністю і простотою. Своєрідне відчуття монолітності й узагальненості форми, графічна окресленість контурів, спрощеність і деформація пропорцій, уміння відсікти зайве сприяли винятковій художній виразності, що грунтувалася на традиціях образотворчого фольклору.

Серед сучасних досліджень української народної ікони можна виділити кілька головних напрямків: релігійно-богословський, фрілософрськокультурологічний та мистецтвознавчий. Методологія класичної та некласичної гуманітарної парадигм дозволяе тлумачити іконографрічні образи як виразні знаки культури та вважати іконічні об'єкти елементами цілого, котре репрезентує всі ознаки певного типу соціокультурної свідомості, в межах якої цей знак фрнкціонуе.

Трансиендентальний вилір народної ікони дослідники окреслюють на релігійно-богословському, фрілософрському та етнокультурному рівнях.

Релігійно-богословський визначае ікону як сакральний простір незмінного самоявлення Бога, безконечного його утілення та благодаті. Образ-ікона належить надчуттєвому світу, відтворюючи Первообраз. Ікона - це передусім подоба (натяк), а не силвол. Філософрська парадигма виявляе антиномічність, онтологічність та синергійність ікони. Згідно 3 В. Лепахіним, ключова антиномія іконообразу - зображення Боголюдини як іпостасі єдиної у своїй сутності й водночас відмінних Божественної та людської природи. Ікона - це антинолія невидимого у видилолу, незображувального у зображеному, неописаного в описаному [2, с. 65]. Архетипи етнокультурного рівня свідчать про співвіднесення 
іконографрічного канону народної ікони з канонол фбольклорних традицій. Народний іконопис відтворюе ті загальні ідеали й цінності, що панують у межах етносу. Народна ікона, як складова культури, утверджує певний іконописний тип. Ї̈̈ канонічні обмеження покликані щонайбільше згладжувати тілесні властивості предметів 3ображення, відтворюючи модель нащіонального типу. На думку Ігоря Федя, народна ікона - це основа трансцендентальних матриць самоідентифрікації людини і нації в цілому [13, с. 9].

Художній вимір народної ікони визначають етнографічний, генетично-суб'єктивний та художньо-технологічний рівні. Так, О. Осадча проаналізувала феномен хатньої ікони кінця XVIII - початку XX століть в контексті метафрізичного (трансцендентального), художнього (суб'єктивного) та фрізичного (об'єктивного) аспектів [4]. На думку авторки, етнографічний рівень виявляе регіональні особливості традиційно-побутової культури; відображає колористичні, семантичні та іконографічні схильності при написанні ікон. Народна ікона на цьому рівні виконуе фрункцію пізнання оточуючого світу й відображення конкретних символів, які передавалися від покоління до покоління й кодувалися в орнаменті, побудові композиції, у зображенні певних елементів буденного оточення. Генетично суб'єктивний рівень пильнує виправлення гріховної природи людини. Він відкриває генетичну здатність людини до духовного зростання. Цей рівень торкаеться психологічних та екзистенщійних аспектів душі людини. На цьому рівня ікона активуе відчування Божественного. Художньо-технологічний (естетичний) рівень завбачає застосування певних технологічних прийомів та засобів художньої виразності. Оскільки народна ікона виконує фрункцію оберегу, посилаючись на основи народного світобачення, традиції та фольклор, то народні іконописці використовували техніку олійного живопису. Об'єктивний вимір ікони характеризується функціональнотипологічним рівнем $\dot{i}$, в едності з релігійно-богословським, довершує коло рівнів.

Отже, френомен народної ікони репрезентує народні традищії, вірування та архетипи; виявляе ознаки місцевої традиційно-побутової культури окремих регіонів України; відкриває закономірності застосування колористичних, семантичних і технологічних прийомів; як частина української художньої культури та мистецької традиції, розкриває дух нації, національну свідомість та обумовлюе національну ідентичність.

Висновки і перспективи. Теоретичною основою сучасних досліджень іконопису є виявлення його трансформацій за певних соціокультурних умов та в системі сакрального мистецтва; аналіз дотримання або порушення іконографрічних канонів відповідно до традицій екзегези; виявлення етнічних, стилістичних, типологічних особливостей української ікони. Перспективи вивчення іконопису пов'язані з методом інтерпретації його об'єктів. Метод іконології за предметним змістом зображення розкриває семантичне значення стилю, техніки виконання та визначає тенденцію розвитку сакрального мистецтва. Крім того спонукає сучасні фрілософрскі, культурологічні, мистецтвознавчі дослідження українського образотворчого та декоративного мистецтва, пов'язаних із виявленням у творах мистецтва архаїчних сакральних символів, існуючих поза історією й незалежно від людини як таких, що з'явилися у давні часи і використовуються у культурі наступних епох.

\section{Список літератури:}

1. Бычков В. В. Русская теургическая эстетика. Москва, 2007. 743 с.

2. Лепахін В. В. Ікона та іконічність. Львів, 2001. 288 с.

3. Овсійчук В. А. Майстри українського бароко. Жовківський художній осередок. Київ, 1991. 400 с.

4. Осадча О. А. Основні художні методи створення просторової складової ікони. URL: http://artisthelen.com/ publications/osnovni-hudozhni-metody-stvorennya-prostorovoyi-skladovoyi-ikony

5. Осадча O. А. Відображення принципів іконічності в іконографрічному образі. URL: http://artisthelen.com/ publications/vidobrazhennya-pryntsypiv-ikonichnosti-v-ikonografichnomu-obrazi

6. Крвавич Д. П., Овсійчук В. А., Черепанова С. О. Українське мистецтво : навч. посібник : у 3 ч. Ч. 2 . Львів, 2004. $268 \mathrm{c}$.

7. Пресіч Ольга. Вивчення символізму в українському іконописі: методологічні зауваги. Всесвіт. Украӥнський журнал іноземної літератури. 2012. № 7-8. URL: http://www.vsesvit-journal.com/old/content/view/1009/41/

8. Руско Н. М. Особливості галищького іконопису кінця XIX - початку XX століть: фрілософрсько-релігієзнавчий контекст : дис. ... канд. фрілософ. наук : 09.00.11. Острог, 2015. 196 c. URL: https://www.oa.edu.ua/doc/dis/rusko_n_m.pdf

9. Скоп П. Історичні передумови виникнення стилю маньеризм в українському мистецтві та причини його появи. Вісник Львівського університету. Серія : Мистецтво. 2013. Вип. 12. С. 168-173.

10. Скоп П. Становлення традицій мистецького стилю маньеризм в сакральному живописі поч. XVII ст. Західної України. Народознавчі зошити. 2011. № 1. С. 101-107. URL: http://nbuv.gov.ua/ujrn/nazo_2011_1_10

11. Степовик Д. Історія української ікони X-XX століть. Київ, 2004. 442 с.

12. Тріска О. Народна ікона на склі другої половини XVIII-XIX століття: европейський контекст [Текст] : дис. ... канд. мистецтвознав. : 17.00.06. Львів, 2009. 178 с.

13. Федь І. А. Трансцендентальні та культурологічні виміри феномена української ікони : дис. ... д. фрілософ. наук : 17.00.01. Київ, 2006. 395 с.

14. Федь I. А. Українська ікона як архетип. Мультиверсул. Філособбський альланах. $2004 . \quad$ № 41. URL: https://www.filosof.com.ua/Jornel/M_41/Fed.htm

\section{References:}

1. Bychkov V. V. (2007) Russkaya teurgicheskaya estetika. Moskva, 743 p.

2. Liepakhin V. V. (2001) Ikona ta ikonichnist. Lviv, $288 \mathrm{p}$.

3. Ovsiichuk V. A. (1991) Maistry ukrainskoho baroko. Zhovkivskyi khudozhnii oseredok. Kyiv, 400 p.

4. Osadcha O. A. Osnovni khudozhni metody stvorennia prostorovoi skladovoi ikony. URL: http://artisthelen.com/ publications/osnovni-hudozhni-metody-stvorennya-prostorovoyi-skladovoyi-ikony 
5. Osadcha O. A. Vidobrazhennia pryntsypiv ikonichnosti v ikonohrafichnomu obrazi. URL: http://artisthelen.com/ publications/vidobrazhennya-pryntsypiv-ikonichnosti-v-ikonografichnomu-obrazi

6. Krvavych D. P., Ovsiichuk V. A., Cherepanova S. O. (2004) Ukrainske mystetstvo: navch. posibnyk: u 3 ch. Ch. 2. Lviv, 268 p.

7. Presich Olha (2012) Vyvchennia symvolizmu v ukrainskomu ikonopysi: metodolohichni zauvahy. Vsesvit. Ukrainskyi zhurnal inozemnoi literatury, no. 7-8. URL: http://www.vsesvit-journal.com/old/content/view/1009/41/

8. Rusko N. M. (2015) Osoblyvosti halytskoho ikonopysu kintsia XIX - pochatku XX stolit: filosofsko-relihiieznavchyi kontekst: dys. ... kand. filosof. nauk: 09.00.11. Ostroh, 196 p. URL: https://www.oa.edu.ua/doc/dis/rusko_n_m.pdf

9. Skop P. (2013) Istorychni peredumovy vynyknennia styliu manieryzm v ukrainskomu mystetstvi ta prychyny yoho poiavy. Visnyk Lvivskoho universytetu. Seriia: Mystetstvo, vol. 12, pp. 168-173.

10. Skop P. (2011) Stanovlennia tradytsii mystetskoho styliu manieryzm v sakralnomu zhyvopysi poch. XVII st. Zakhidnoi Ukrainy. Narodoznavchi zoshyty, no. 1, pp. 101-107. URL: http://nbuv.gov.ua/ujrn/nazo_2011_1_10

11. Stepovyk D. (2004) Istoriia ukrainskoi ikony X-XX stolit. Kyiv, $442 \mathrm{p}$.

12. Triska O. (2009) Narodna ikona na skli druhoi polovyny XVIII-XIX stolittia: yevropeiskyi kontekst [Tekst]: dys. ... kand. mystetstvoznav.: 17.00.06. Lviv, 178 p.

13. Fed I. A. (2006) Transtsendentalni ta kulturolohichni vymiry fenomena ukrainskoi ikony: dys. ... d. filosof. nauk: 17.00.01. Kyiv, $395 \mathrm{p}$.

14. Fed I. A. (2004) Ukrainska ikona yak arkhetyp. Multyversum. Filosofskyi almanakh, no. 41. URL: https://www.filosof.com.ua/Jornel/M_41/Fed.htm 